\title{
Direction of Chinese Legal Education Reform under the Legal Professional Qualification Examination*
}

\author{
Zehua Feng \\ Graduate School \\ Chinese Academy of Social Sciences \\ Beijing, China 102488
}

\author{
Pengwei Zhan* \\ Law School \\ Guangdong University of Foreign Studies \\ Guangzhou, China 510006 \\ *Corresponding author
}

\begin{abstract}
Chinese legal education will be reforming in five aspects under the legal profession qualification examination. Firstly, the law teachers will pay more attention to legislative and administrative law course. The setting of course will trend to be more scientific and more reasonable. Secondly, the original judicial examination has been difficult to integrate the legal professional community, but the trend of the integration of legal profession community will be more obvious under the new situation. Thirdly, legal profession qualification examination is an important link in carrying out the rule of law comprehensively, high standard and high quality talented person will be more necessary. Especially in the environment of market economy, compound law talents are the first choice to various industries. Setting up versatile law talents cultivation mode will be helpful to send more high quality law talented person to market economy society. Lastly, it is an important means for China to strengthen the investigation of case questions in the legal profession qualification examination, as a result, the method of case teaching will be popularized allaround.
\end{abstract}

Keywords-legal profession qualification examination; legal education; legal professional community; legislative science; administrative law

\section{INTRODUCTION}

Since 2002, judicial examination has been an important way to choose law talents in China. In the past 15 years, the judicial examination has made remarkable achievements and has selected a batch of professional talents who can guarantee the social rule of law in the modernization drive of China. The legal profession community is also increasingly formed in this examination. In this process, Chinese teaching mode of law has been adjusted accordingly. For example, some universities adjust their teaching arrangements for three and half years to three years, and some just cut down the course and shorten their time for class in the first term of senior. Though the ways of educational reform are varied, they all reflect pragmatism in education of these schools. Unfortunately, the legal education is not conducive to the cultivation of legal literacy of law students, which leads to a

*The article was written by Feng Zehua who is the doctoral candidate in Graduate School \& School of Marxism, Chinese Academy of Social Sciences and Zhan Pengwei who is the master degree candidate in Law School of Guangdong University of Foreign Studies. lower percentage of law undergraduates in the judicial examination than non-law undergraduates. So as to speed up the promotion of rule in law policy and accelerate the form of legal professional community, China will change judicial examination to legal profession qualification examination in 2018 , which go a step further to give a chance to people who related to deal with legal dispute to fuse in legal professional community, such as legal adviser, legal affairs, assessor of administrative penalty, administrative reviewer, administrative adjudicate staff, arbitrator and so on. China also cleared that the undergraduate law student must already graduate from school if they want to take part in the legal profession qualification examination. Under the new situation, it seems that almost all the job related to law must pass the qualification examination if someone wants to engage in legal profession. The purpose of legal profession qualification examination institution is mostly aimed to shorten the distance of legal professions and realized the management to law worker, for which is the normal way of legal state all around the world. If there is no threshold to enter legal profession, it's hard to be a professional legal worker. In China, law education generally set in the undergraduate stage, and a few colleges will also set up legal secretary, legal practice, lawyer assistant major and so on. Needless to say, in order to adapt to the legal professional qualification examination, the teaching outline of law school will have some significant changes and gradually return to the essential level of legal education. Throughout the relevant views of reform, and combined with the trend of overall promoting rule of law, Chinese legal education will be reforming in five aspects, and the following test will focus on expounding these five aspects.

\section{IMPORTANCE ATTACHED TO THE CURRICULUM OF LEGISLATION}

Under the reform of legal profession qualification examination, the state encourages that the legislator should obtain a certificate of legal profession qualification. This is a great breakthrough in scientific legislation. In the past, legislative drafters mostly were the core members of the standing committee and government departments, many of them didn't have the background of major in law. Some people may also study for a Juris Master degree in non-law background due to the need of work. However, the part-time 
Juris Master degree education model has been criticized for many years for graduated decide on a thesis and few people real participate in classes, which makes the part-time Juris Master diploma are highly questioning by others. It's not surprised that though some legislative drafters are very diligent, the legal education still lack of systematically develop. Accordingly, the quality of the legislation can be imagined in many local authorities.

When all the law students work hard for a legal professional qualification certificate, it will be inevitable that a large number of people will try their best to get this certificate. Under the same conditions, people who have got this certificate will have a higher legal professionalism than the person who without the certificate in the form. Then, when recruiting staff, the legislature will give priority to those who have a legal professional qualification certificate. At present, this trend has already shown up in some coastal cities which are economically developed. Especially, drafting national laws requires legislator to have a higher legal professionalism. Our article believes in standing Committee of the national people's congress would make a law to stipulate that while recruiting legislation drafters and the drafters must have some relevant legal professional qualification certificates. Therefore, the legislative drafters must have the legal professional qualification are not only the requirements of the times, but also the requirements of scientific and professional legislation. The person who can take in the legal professional qualification examination must have a legal undergraduate diploma or master of law diploma, which can certain that the legislative drafters have received a system legal education. In the process of legal education, many universities tend to ignore the course of legislation. Nowadays, even if the students who have not graduated from school can no longer take in the legal qualification examination, the educational pragmatism is still going on in law schools. As a result, legislation will likely to become a compulsory subject.

Legislation is a branch of law that specializes in the law activities. From the nature of legislation, it is an important subject between legal practice and legal theory. Studying legislative science deeply is of great significance to promote the scientific and professional of Chinese legislation and improve the quality of legislation. However, many universities always set the course of legislation as an elective subject or ignore the course directly for many years. The vast majority of law students even never heard of the existence of this course, which led to the first time they heard this noun at the stage of master's degree. This kind of legal education unilaterally emphasizes the cultivation of students' basic knowledge, but neglects to disentangle the background various departments' law and research the technology of legislation. So, it is not conducive to provide high-quality legislative personnel for many legislative departments in China in the long run. Therefore, under the new situation, the legislation course must be paid more and more attention by the universities. In the reform of legislative course, universities should according to their actual situation to set up a reasonable and scientific curriculum plan and training students' legislative thought in a real way. First, in some comprehensive colleges which have not set a major of legislation can coordinate with reduce the class hour of other law courses, and integrate the remaining hours as the total teaching hours of legislation. The newly established legislative courses can be tentatively set between 36 and 54 class hours.

At the same time, we recommend that the legislative courses be set in the second semester of junior because law student have already exposed to most of the department laws systematically at that time. Law students will have a deeper understanding when they study legislation. Setting the legislation as compulsory course or not will according to the actual situation of university. For example, it is not appropriate to set legislation as a compulsory course in some non-comprehensive universities, such as medical colleges, polytechnic universities and military police academies. As these universities generally emphasize to cultivate the other aspect knowledge of law, the time to study law is relatively scarce, if we pay too much attention to the independence of legislation, it's hard to avoid adding students' learning burden, which is not helpful to foster students' knowledge of other department. Thus, these universities can place legislation as an optional course according to their actual situation. At the same time, in order to reflect the importance of legislation, curriculum designers can give law students a number of class hours in the course of jurisprudence to study legislation. Second, if some institutions have already set up legislation major, they can set it as a compulsory course. Since these schools have already form a regularity known about teaching legislation, the class hour can be set about more than 54 hours. At present, the city with districts has a certain legislative power. Local legislative activities will flourish in the future for a long time. Therefore, these universities which have sufficient teaching hours should not only teach the law students about the general situation of legislation, but also teach the relevant local legislation knowledge. The universities under these two modes except cultivate the basic knowledge of legislation could also guide law students to participate in the relevant legislative mission of teachers according to their own situation. Especially in recent years, some local authorities have often published the legislation draft to society as to solicit the views of the public. The teachers of the legislative science can guide their students to participate in these activities, and can even take these as the standard of judging assignments or the final examination results. Under the condition of literally and practical learning, law students can not only gain the pleasure of studying legislation, but also can improve the quality of the legislation in China indirectly when they participate in the national legislative activities as citizens.

\section{IMPORTANCE ATTACHED TO THE CURRICULUM OF ADMINISTRATIVE LAW}

Administrative law is regarded as the youngest law in the several apartment laws in China. Since new China was founded, it's hard to find a case that people sued government, it's sure that government would not damage the rights of the people because the government regards serving the people as the tenet. Due to the existence of these thoughts, it had 
directly set many obstacles to draft Law of Executive Accusation. Whatever, the Law of Executive Accusation had finally been enacted in 1990s under the huge stress from the society, the issue of this law have ensured the citizen have the right to suing government and perfected the system of Chinese administration law, and it have a great historical significance. Henceforth, the study of Chinese administrative law has opened a new side. In the early stage of the implement administrative procedure law, because of its own problems, citizens have encountered many difficulties in the process of administrative litigation. The success rate of people suing officials' case has been maintained at less than $10 \%$. For this reason, the administrative law is viewed as a "underdog" in the legal profession. Students study administrative law is fewer than other departments and many universities compress the recruiting scale of administrative law major. But with the appearing of administrative reconsideration law, administrative licensing law, administrative penalty law, civil servants law, state compensation law, administrative enforcement law and so on. The system of administrative law is becoming more and more perfect, the rights of citizens are further guaranteed, and more and more people study administrative law. However, compared with other departments, the scholar in administrative law is still fewer than other departments, especially in many colleges, the enter number of administrative law students even lower than the criminal law.

In 2015, after the amendment of the administrative procedure law, especially established the institution of record registration, citizens' administrative appeal and its success rate are guaranteed. As an important part of promoting rule of law policy comprehensively, legal professional qualification examination also stressed that the government departments engaged in administrative punishment decision review, administrative reconsideration, administrative decisions of the personnel must obtain legal professional qualifications and the state encourages other administrative law enforcement personnel to obtain a professional qualifications, which means that anyone who wants to engage in the aforementioned profession must pass the legal professional qualification examination. In the past, many administrative penalty, administrative reconsideration and administrative decisions related personnel did not have corresponding qualifications. The aforementioned related occupations personnel are less of legal professional training. Their civil service examination may better than law professional students. But they never accepted legal education systematically, which makes their go program training effect always not so well. Over these years, the administrative penalty and administrative reconsideration decisions of some local governments have been criticized a lot in China. It's common to find decisions defy superior laws and violate the principle of proportionality. Limited to the incompetence of the administrative procedure law at that time, although some administrative penalty decisions are riddled with errors, the success rate of administrative proceedings by citizens is still very low. While Some citizens are lucky to win the lawsuit, the administrative subject does not perform the judgment, which led to a non-rule of law phenomenon that citizens prefer letter and petition but not trust law, so that some local governments' finance for the maintenance of stability are at the forefront. These phenomena fully show that the administrative body, especially in the administrative penalty, administrative reconsideration, administrative adjudication related functions of the staff, and its legal literacy needs to be improved.

In the inside of administrative subject, people who engaged in administrative punishment, administrative reconsideration and administrative adjudication are not in a few. Since these new employees must obtain the legal professional qualification examination, this means that the percentage of administrative law scores should be increased legal in the professional examination in the future. From 2002 to now, it's not surprise to see the score of civil law and criminal law exceed 95 points, which stay its average at 92 points and it's easy to find the score of law of criminal procedure over 70 points, which even high to 82 points at 2012. However, it's not so lucky for administrative law, which stop at about 60 points and even down to 40 points in one year, just can't compete against the traditional "big law" - civil law and criminal law. This phenomenon expose how administrative law unpopular by educational circles directly. It maybe the judicial apartment doesn't want to foster law professional who focuses on law of executive accusation either. No matter what we are discussing, the situation of neglect or take no account to administrative law must be broken up in the new legal professional qualification examination.

In the past, due to the low position of administrative law, a lot of universities only set 60 hours to study this knowledge, some even just set about 54 hours, which is close to the study time of introduction of civil law and general provisions of criminal law. Besides, the civil law also concluded contract law, marriage and family law and so on, which a lot of universities always arranged the class time approach to 200 hours. Criminal law always set more than 108 class hours, which is not concluded the study time of law of criminal procedure. Return to administrative law, this 60 class hours, not only included the study of administrative law itself, but also contained the study of law of executive accusation. Look back to the system of administrative law, the knowledge it need to study is no less than civil law and criminal law, but just like we mentioned above, there is an awkward situation results from people put administrative law in a low place, when many universities arranged the course of administrative law, they only simply study the important contents of administrative law practically, and neglect some chapters, such as state compensation law. But, needless to say that, the status of administrative law must improve and people who study this knowledge will increase too under the new situation. If they don't engage in the study of administrative law, it's hard for them to pass the legal professional qualification examination, more ever, it will be harder for them to adapt to the future administrative work. There is no doubt that the judicial examination was the threshold for judge, inspector, lawyer and notary originally. So the judicial apartment averaged the needs of theoretical knowledge for these four professions in general terms when setting the test paper. For these for professions, nothing can 
be more popular for them than criminal law and law of criminal procedure. No matter the judge, inspector or lawyer, those two kinds of law is necessary needed, which leads to the score of criminal law and law of criminal procedure in judicial examination remained stubbornly high in the past. But under the reform of legal professional qualification examination, the ratio of administrative law in this exam will only improve but not decrease. Accordingly, the teaching pattern in the past which disparage administrative law and flatter criminal law must change.

Thus, one of the reform directions of legal education in the future is that improve the importance of administrative law in concept, and arrange course of administrative law more reasonable in act. Specifically, the arrangement of administrative law in many universities is extremely unreasonable, which is disadvantage to foster more and more law profession who specialized to administrative legal works. Firstly, the course designers should increase the class hours of administrative law to at least 80 hours, and if conditions admit, some universities can also up the class hours of administrative law to 108 hours. Class hours are the foundation to ensure student have ample time to study the theory of administrative law. If there is too little class hours for student who major in law, it's hard for them to know the quintessence of administrative law well. Secondly, the course designers should arrange the teaching of administrative law based on case analysis and assist with theory discuss. Undergraduate education as a general education, it's not appropriate to teach the theory full of disputes to undergraduate students. As to arouse students' interest to study administrative law, lively and interesting case analysis part is necessary. Through the case analysis, the law students can not only study all kinds knowledge of administrative law, but also can understand the profound mystery of administrative disputes in advance.

\section{Focus on Training Law Students' Professional COMMUNITY CONSCIOUSNESS}

The initial purpose of setting judicial examination was just to set a threshold for four professions, namely, judges, prosecutors, lawyers and notaries, which led to the narrow legal profession community was confined by these four kinds. From the current practice, the narrow sense not only failed to cultivate the consciousness of professional community of the legal persons, but also constantly destroyed this consciousness. Especially, the contradiction between judges and lawyers has not been coordinated in recent years. These two kinds of occupation conflict was nonsense, theoretically speaking, it does not happen with contradictions because the judges decide cases and lawyers just in charge of debate. The subconsciousness of this law is still valid in the western rule of law countries. In China, the variety of complex judicial environment mixed together becomes a matter of course. Of course, the contradiction between the prosecutor and the lawyer can be understood; after all, these two occupations are naturally antagonistic. It is necessary for lawyers to prevent the public prosecutor from intentionally infringing on the legitimate rights and interests of citizens. Under the new situation, the main body of legal profession community is not confined to the four contradictory jobs. From the relevant documents, it can be found that the arbitrators, legal advisers, administrative penalty decisions, administrative review and legislative drafting will become the subject of the legal profession community. In other words, the new law professional qualification examination just moves the existing legal community of the broad sense of law directly, which made legal profession qualification test suddenly become a great family of legal professionals.

In the past, the law school did not consider the importance of establish legal occupation community in the curriculum, which led to the contradictions among the various positions in the practice extremely outstanding, and it seems like to kill each other. The long existence of such an atmosphere is not conducive to the steady progress of Chinese rule of law policy, and ultimately hurt rights and interests of every citizen. Therefore, under the new situation, the curriculum designer should take the commonality with interdisciplinary knowledge of departmental law between various legal occupation consciously to law students consciously, let students understand the law between the law professional occupation should be harmonious situation, which can really advance the progress of the rule of law in China. In particular, the legal occupation qualification examination will also increase the legal occupation moral examination efforts under the new situation, which means that the legal occupation ethics between the community will become a hot spot, the study also aims to promote the formation of legal occupation community. In some of the conditions of the political and legal institutions, Comprehensive University School of law department also set up more than a community of law occupation related courses for law students elective according to the law courses arrangement.

\section{THE TREND OF TRAINING OF COMPOUND LAW TALENTS IS OBVIOUS}

The reform of the legal profession qualification examination is one of the most important steps in carrying out rule of law in an all-round way. It is an important mission of the legal profession qualification examination to select high-quality legal personnel who can adapt to the development of the market economy. Under the new situation, almost all areas of society need legal professionals to intervene in order to expedite each link legally and effectively. In the past, Chinese market economy lack of legal professionals, which lead to the phenomenon like constantly contract in a high default rate and difficult to implement, borrow money don't return, and other phenomena and so on, as a result, social integrity plummeted. Moreover, due to the diversification and complication of market economy subjects, it is difficult for single legal knowledge to adapt to this kind of multiplex request. In particular, some industry intervention requires higher level background knowledge of legal professionals to truly coordinate. For example, if legal occupation has not related medical knowledge in a medical dispute, it is difficult for him to play a positive role in the process of mediation, 
reconciliation and litigation, but will only end in report of the forensic identification or identification of personnel as the only certificate. This passive situation has occurred again and again, forced some legal professionals to cope with a higher second professional background.

Therefore, it is necessary to attach importance to the training of compound law talents under the new situation. Specifically, colleges and universities can continue to promote the marriage of law and other disciplines in accordance with the relevant subject resources in the school, and jointly cultivate a compound law talent. Take the property tax law as an example, if the financial tax law practitioners do not have the background knowledge of financial accounting but only have the knowledge of Finance and taxation, it's bound to be difficult for the actual operation of the accounting office. The course designer will set up a number of illegal professional electives for law students, such as finance, accounting, economics, management, finance, etc. for the free choice of law students. Generally speaking, in a small number of law schools, can public the illegal school elective courses contents in advance for law students, and open the few most popular course according to the actual situation which vote by student. For the courses that fail to offer, law schools can offer opening courses video in some university to other law students who are interested in these knowledge. In the other larger law school departments, more types of illegal learning courses should be provided for students to take courses. Law student study non legal courses, is one of the most important links in the training of compounding law talents. And it also needs to cultivate a team of compound teachers if we hope this training model can run in a long term. Under the training mechanism of compound law undergraduates, the professional quality of law teachers will inevitably be improved either, otherwise it will be difficult to accept the knowledge impact brought by complex training. The socalled "keep on learning as long as you live" told us that as a law teacher who should set up a lifelong learning concept. Law teachers should not neglect their own professional knowledge, and should take practical actions to lead studying other professional knowledge. Talking about the construction mechanism of the compound teaching staff orally is easy to fall into the situation of the impure construction mechanism mentioned above. The key to the success of this mechanism is how to create a condition to encourage law teachers to engage in interdisciplinary research. On the one hand, for the new teachers, when evaluating teachers professional title in law, request law teachers must published more than two interdisciplinary articles or papers to encourages the law teachers engaged in the work of interdisciplinary research of theoretical engineering, medicine and medical etc, teachers who will be given more priority to cross the disciplinary research under the same condition. On the other hand, for the teachers who have already evaluated the corresponding titles, the corresponding mechanism should be designed in the evaluation of the annual outstanding or application. Under the same conditions, if a teacher has more interdisciplinary research results during the year, priority will be given to teachers who have more interdisciplinary research results. In the application of various subjects, priority should be given to interdisciplinary applications. In this kind of atmosphere, law teachers are definitely going to be more active in studying the knowledge of other subjects.

The ideal is always beautiful while the reality often cruel If there is difficult for some law school to mobilize resources of other disciplines, they can encourage law students to study other professional degrees. If there have no conditions, schools can encourage law students to minor other professional degree. Take the existing medical college as example, many medical universities have set up a law major, however, because the difference between law and medical science, many medical schools do not allow law students to learn another professional degree at the same time, and only offer minor service. Compared to the honor bringing by double degree, the purpose of inter-disciplinary law talent teaching mode is to promote law students really master other professional knowledge, rather than indicate their level by having other professional degrees. Under the guidance of this kind of educational pragmatism, law majors should also take a minor major initiative, such as pharmacy, Chinese medicine and so on. In the course of minor course, law majors should coordinate their progress of law course and minor course as much as possible, and find their own pleasure in studying medical science and law. This kind of compound law talents training mode will transport more high-quality talents for the society eventually.

\section{WIDE SPREAd OF THE CASE TEACHING METHOD}

The legal profession qualification examination will mainly contained the questions based on cases updated every year, which means that the scores of case questions will be greatly raised thus come to a big change in the mark distribution of exam. In the past, the original judicial examination test was divided into four parts----the former three test papers covered multiple choice and case analysis and theoretical discussion subject on the last paper. The question setting with the large number of multiple choice is not reasonable in that law students can easily pass the exam just through a rigid memory without rigor legal thought. Generally speaking, different teachers bear different mind to the answer, so the focuses on the related theories are varied. Most of the time, law students will mistakenly choose inaccurate theories under the influence of a specified theory. It may be one of the reasons why the passing rate of the examination of law students is lower than that of the students who don't major in law. Non-legal students do not receive legal training systematically, so "following what others say" is the natural result of experiencing institutions training. There is no doubt that acquiring the relevant knowledge can pass the judicial examination. Instead of paying too much attention on system law theories that may invoke a lot of wonders in law majors' mind, non-law majors' just need to be preoccupied with test-taking skills so that they could easily tackle the test questions. Therefore, although the judicial examination does provide a large number of legal talents for the rule of law of China, its question model draws criticism.

In the new form of test paper setting, case questions can use a multiple-choice questions form. But this doesn't seem 
compatible with the trend of reform. According to the relevant views, enhancing the proportion of case questions examples clearly illustrate that reformers are going to expand the fourth part of judicial examination. It likely happens that the first two papers are turned into the objective questions and the rest are subjective questions. This thought of reform means a return back to the problem-solving. After all, in reality, the work of the legal profession do not lie in how to learn to do multiple-choice questions well, but to write legal documents and settle specific disputes. The original mode of judicial examination set a lot of multiple-choice in order to do the examiners a favor in marking. This does a great harm for selecting the persons who have genuine knowledge of law and have strong capability in legal documentation writing. Now that the legal profession qualification examination value case tests, the law schools should change their educational models.

At present, case teaching method, from a certain aspect, is gaining steam in some law schools. Compared with other disciplines, law education should pay attention to the cultivation of practice. If a law teacher just instills some rigid and lifeless theories into the law students, they will find it's difficult for their students to apply knowledge to practice and comprehend the essence of the discipline. The case teaching method is a great magic weapon to attract students. As the case is incorporated with lots of life elements and closer to the real side of society, law students can naturally feel the meaning of the course in this atmosphere. In particular, when teachers flexibly set the professional knowledge in these cases and perfectly solve the disputes in the case, they can attract more law students to acquire knowledge. It's easy to explaining the importance of case teaching method from general framework. Still, it's very difficult to flexibly using case teaching method to encourage students to participate in the study. Currently, many teachers just copy the cases in the daily life in class. Teachers fail to present some cases to students for their research due to several factors such as the uneven level of teachers' teaching and course arrangement. In fact, the most simple loan contract disputes contain a lot of departmental law knowledge; some are even involved in the technologies of evidence collecting. Such a complex method of case teaching extremely test each teacher's teaching.

This paper takes an example of the judicial examination training that accepted by Professor Liu Fengke, an associate professor of Beijing Technology and Business University so that mainly explaining a vivid and interesting case teaching method. It is said that Liu enjoyed a noble position in the field of judicial examination training. He started his training career in 2006. Since that, Liu has been praised by many examinees of judicial examination as "Great Emperor of Fengke". It is the lively and interesting teaching methods that make his judicial training class most enduring excellent. If we carefully read many of criminal law teaching books written by Liu, we will find that his book has several key figures: Zhang Erwa, Li Cuihua, Zhang Sanwa, Zhang Siwa etc.[3] Liu can always skillfully combines these characters together when teaching every criminal case. For example, Zhang Erwa, as the leading role in his case, started his bad behaviors with roguery in the form of picking and stealing. Finally he became the deputy leader of "Axe Gang". During the period, Erwa violated theft, robbery and so on. And then he organized organized criminal gangs, even bribed officials in the municipal engineering. Li Cuihua, as the heroine, often acted as the object of some sexual crimes. Occasionally, $\mathrm{Li}$ Cuihua will become the girlfriend of Zhang Erwa. In the course of the case teaching, Liu arranges the theory of criminal law in a good order, explaining the legendary life of Erwa. At the same time, Liu spares no effort to attach more interesting and hot cases to Erwa. Law students are so interested in criminal law under Liu's teaching mode that they become eager to learn and answer Erwa's crimes in these years, including how to deal with and judge the continuous criminal behaviors of Erwa after he went out from the prison. The case teaching method not only closes to the daily life and attract the majority of candidates for examination, but also make law students absorb the related science of criminal law unconsciously. Thus, the feature of this case teaching method consists in it can grasp students' curiosity set some teaching case according to the age of students especially the adolescents. The choice of characters in the whole case doesn't separate from the continuation of legal knowledge. In order to cater to young people's interest in serial soap operas, Erwa acts as the subject of crime all the time.

According to the regular pattern of law education, this paper uses the experience of judicial training to explain the mode of legal education. After all, students could be learned through various legal teaching methods. The teaching of other department law can also refer to this teaching mode or even popularized it. For example, procedure law, which is regarded as the most boring law in the law course, can apply the case teaching. This requires teacher to spend a lot of energy to search for cases which can be properly set in the current process of litigation. When teacher arrange the relevant cases, the party is no longer "Zhang San, Li Si or others". They can follow the teaching method of Liu Fengke, using "Zhang Erwa" and other similar characters. Only in this way, law students can gain more pleasure and concentrate on study. At last, the classroom atmosphere can be actively promoted.

\section{CONCLUSION}

With the reform of legal professional qualification examination, China's legal education should make some changes. It is necessary for the education departments and the law schools to set up the curriculum which are suitable for the legal qualification examination. So the promotion in the training of legal talents in China could happen. In the new era, there may have many unpredictable changes in the society. Therefore, universities need to take social needs into account when setting courses.

\section{REFERENCES}

[1] General Office of the Central Committee of the CPC and General Office of the State Council is issued the opinions on perfecting the 
national legal professional qualification system[EB/OL].www.gov.cn, 2016-8-20.

[2] Zhu Liyu, Zhang Shuguang. Legislative Science [M].Beijing: Renmin University of China Press, 2009:2.

[3] Liu Fengke. Lecture Notes of Houda: Liu Fengke's Theory on Criminal Law [M]. Beijing: China University of Political Science and Law press, 2015. 